\title{
Benthic macroinvertebrate assemblages as indicators of water quality applying a modified biotic index in a spatio-seasonal context in a coastal basin of Southern Chile
}

\author{
Ensamble de macroinvertebrados bentónicos como indicadores de calidad de agua \\ a través de la aplicación de un índice biótico modificado en un contexto \\ espacio-estacional en una cuenca costera del sur de Chile
}

\section{Pablo Fierro', Carlos Bertrán ${ }^{1}$, Maritza Mercado ${ }^{2}$, Fernando Peña-Cortés ${ }^{3}$, Jaime Tapia ${ }^{4}$, Enrique Hauenstein ${ }^{3}$ and Luis Vargas-Chacoff ${ }^{1}$}

\author{
${ }^{1}$ Institute of Marine Science and Limnology, Universidad Austral de Chile, Independencia 641, Valdivia, Chile. \\ luis.vargas@uach.cl \\ ${ }^{2}$ Benthos, Laboratory of Aquatic Entomology, Ruta T-350, Km 12, Valdivia, Chile \\ ${ }_{3}^{3}$ Territorial Planning Laboratory, Universidad Católica de Temuco, Manuel Montt 56, Temuco, Chile \\ ${ }^{4}$ Institute of Chemistry and Natural Resources, Universidad de Talca, Avenida 2 Norte 685, Talca, Chile
}

\begin{abstract}
Resumen.- Se caracterizó la calidad del agua en un río del sur de Chile a través de un Índice Biótico, en un contexto espacio-temporal y además se analizó la composición y distribución de macroinvertebrados bentónicos y su correlación con 14 parámetros físico-químicos. La toma de muestras ocurrió durante un año en 5 estaciones de muestreo en la cuenca del río Boroa. Se registró un total de 77 taxa, los órdenes más representativos fueron Ephemeroptera (43,30\%), Diptera $(24,16 \%)$ y Plecoptera $(18,03 \%)$. Las especies más abundantes fueron Meridialaris diguillina, Nousia maculata (Ephemeroptera) y Limnoperla jaffueli (Plecoptera). Acordando al IBF modificado (Índice Biótico de Familias) los resultados indicaron excelente, muy buena y buena calidad de agua, la última calidad fue registrada principalmente en invierno. Los parámetros fisicoquímicos así mismo indicaron calidad de agua excepcional. Estos resultados indican un bajo nivel de impacto antropogénico en la cuenca. Al aplicar el Índice Biótico de Hilsenhoff modificado basado en macroinvertebrados, la influencia de la estacionalidad sobre la calidad del agua fue evidente.
\end{abstract}

Palabras clave: Estacionalidad, ríos chilenos

\begin{abstract}
The water quality in a Southern Chile river was characterized using the Biotic Index in a spatioseasonal context, to analyze the composition and distribution of benthic macroinvertebrates and their correlation with 14 physico-chemical parameters. Sampling was done over a year at 5 sampling stations in the basin of the Boroa River. A total of 77 taxa were recorded, with the most represented orders being the Ephemeroptera (43.30\%), Diptera (24.16\%) and Plecoptera (18.03\%). The most abundant species were Meridialaris diguillina, Nousia maculata (Ephemeroptera) and Limnoperla jaffueli (Plecoptera). According to the modified FBI (Family Biotic Index), the findings indicated excellent, very good and good water quality, the latter quality being registered principally in winter. Likewise, the physico-chemical parameters indicated exceptional water quality. These results suggested a low level of anthropogenic impact in the basin. Applying the modified Hilsenhoff Biotic Index based on macroinvertebrates, the influence of seasonality on water quality was evident.
\end{abstract}

Key words: Seasonality, Chilean rivers

\section{INTRODUCTION}

Benthic macroinvertebrates constitute the most suitable group of organisms for evaluating river water quality for organic contamination (Figueroa et al. 2003, Giacometti $\&$ Bersosa 2006, Oscoz et al. 2007). This is due to the fact that: (1) They are relatively easy to sample qualitatively or quantitatively; (2) good identification keys exist for the majority of the orders (Zamora-Muñoz et al. 1995); (3) they interpret the state of the environment from the events of the preceding months (Alba-Tercedor 1996); (4) for most orders there are a number of studies on tolerance 
levels at the family level (Hilsenhoff 1988, Roldán 1999); and (5) they are very sensitive organisms with low mobility, therefore any alteration in the environment (natural or anthropogenic) may cause them to disappear or present reduced abundance. Species which are more tolerant to the contamination may be present in increased densities while others disappear (Alonso \& Camargo 2005). The Family Biotic Index (FBI), initially developed for South African rivers by Chutter (1972), was modified by Hilsenhoff (1988) for application in the rivers of the Northern Hemisphere. This index uses the abundance and diversity of macroinvertebrates in a stretch of river, assigning each taxon a tolerance value. Figueroa et al. (2003, 2007), modified this index, adapting it to families present in Chilean waters. Importantly, even though this index only works for a certain taxonomic level, it is widely used, since it is a practical method which has the advantage of reducing the time needed to identify the fauna (Furse et al. 1984, Warwick 1988, Figueroa et al. 2005), however, the index assumes the same tolerance value for all the species or genera of a given family. For example, Mandaville (2002) established a certain tolerance value for a family Trichoptera, but assigned a different value to one genus belonging to this family; this may produce an underestimation or overestimation of the water quality according to the index. In this study we propose, in agreement with Guerold (2000) and Waite et al. (2004), that in order to obtain more precise results and a better ecological interpretation, the analysis should include lower taxonomic levels.

In the south-central zone of Chile $\left(36^{\circ} \mathrm{S}\right.$ to $\left.47^{\circ} \mathrm{S}\right)$, studies of macroinvertebrates have been carried out in several regions: Biobío (Habit et al. 1998, Valdovinos 2001, Moya et al. 2009a, ), Araucanía (Leiva 2004), Los Ríos (GuevaraCardona et al. 2006), and Carlos Ibañez del Campo (Mercado \& Elliott 2006, Oyanedel et al. 2008, Moya et al. 2009b); the majority of which only analyzed the structure of the ensemble of macroinvertebrates.

Coastal river basins are among the most dynamic ecosystems on earth, with enormous spatial and temporal complexity (Peña-Cortés et al. 2006). They are often influenced by continental run-off waters which are rich in nutrients derived from urban, agricultural and industrial activity (Martínez \& Esteve 2007). Their rivers run down from coastal mountain ranges and are characterized by a great variability in space and time and in their physicochemical characteristics. This is reflected in the structure and organization of the macroinvertebrate community (Hawkins \& Sedell 1980, Vannote et al. 1980).

The objectives of this study were 1) to describe the composition and distribution of freshwater benthic macroinvertebrate communities and their correlation with the physico-chemical parameters of the water and, 2) to characterize the water quality in the Boroa River, Southern Chile, using a spatial and seasonal analysis, applying modified Hilsenhoff Family Biotic Index (IBF).

\section{Materials AND METHODS}

Invertebrates were sampled in the Boroa River basin $(12,910.73$ ha), located in the Coast Range of the Araucanía Region $\left(39^{\circ} 13^{\prime}-39^{\circ} 21^{\prime} \mathrm{S}\right.$ and $\left.73^{\circ} 01^{\prime}-73^{\circ} 10^{\prime} \mathrm{W}\right)$, whose waters drain into the Queule River (Fig. 1). The area has

Figure 1. a) Location of the Boroa River basin in the coastal zone of the Araucanía Region. b) The sampling sites in the basin are indicated with numbers / a) Localización de la Cuenca del Río Boroa en la zona costera de la Región de la Araucanía. b) Las localizaciones de los sitios de muestreo en la cuenca están indicados con números
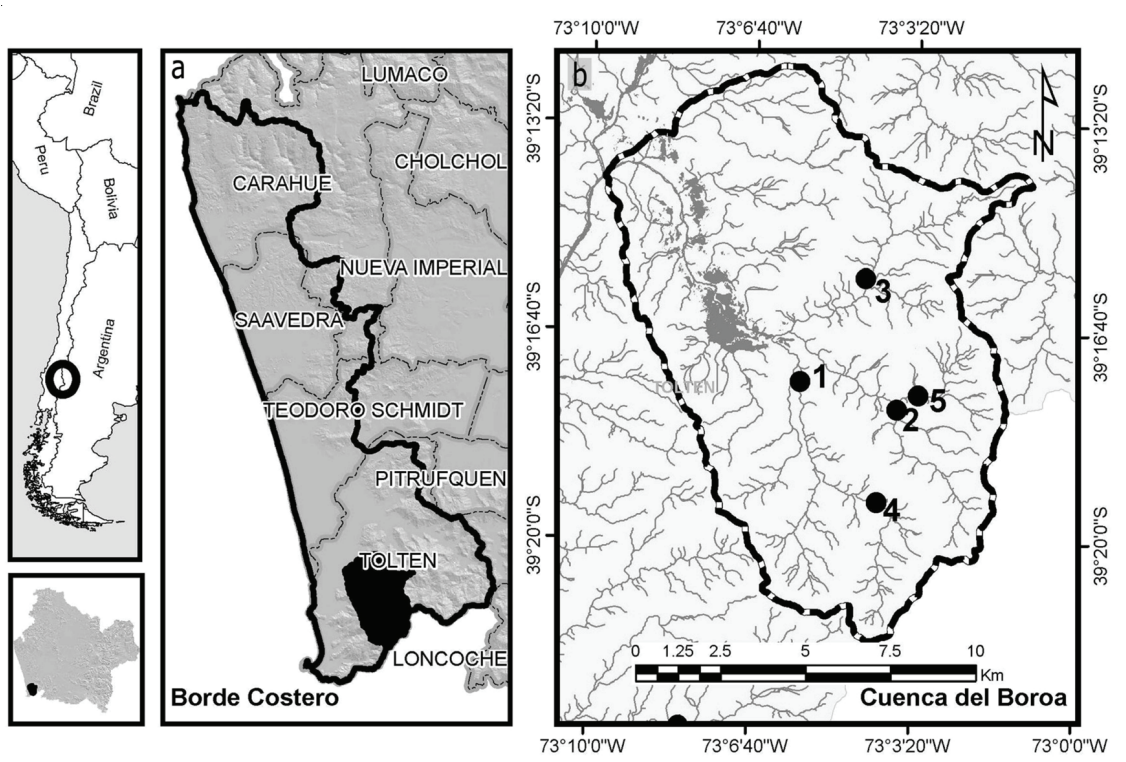
a temperate rainy climate with Mediterranean influence. The soil use is mixed, including native forest (Nothofagus spp.), forest plantations (Eucalyptus spp.), agriculture, cattle farming and swamp forests (Peña-Cortés et al. 2011). The principal river discharge period occurs in the months from May to July and is related to the winter rains. Sampling was carried out seasonally over a year: winter (2008), spring (2008), summer (2009) and autumn (2009). Five sampling stations were chosen, taking into account different levels of human impact (Fig. 1). Three replicates were taken in each site with a Surber net $(0.3 \mathrm{~m} \times 0.3 \mathrm{~m} ; 0.5$ $\mathrm{mm}$ mesh). Station 5 was not sampled in winter due to the heavy flow of the river. The samples were fixed in ethanol $70 \%$, sorted and identified mostly by the use of taxonomic keys (Caamaño 1985, Fernández \& Domínguez 2001, Domínguez \& Fernández 2009), using a stereoscopic magnifier and a stereomicroscope.

Temperature, $\mathrm{pH}$ and conductivity were measured at each station. The water samples were collected in plastic bottles and taken to the laboratory for the determination of the following parameters: biochemical oxygen demand (BOD5), suspended solids, apparent colour, turbidity, dissolved oxygen, chlorides, sulphates, total dissolved solids, true colour, nitrates and phosphates. All the methods of analysis used followed those presented in APHA (1992) (Standard Methods for the Examination of Water and Wastewater). All these variables were used to obtain water qualities according to the secondary environmental quality standard for the protection of Chilean continental waters (NSCA) (Table 1).
Table 2. Water quality classification system based on the Family Biotic Index (FBI) values (Hilsenhoff 1988) / Sistema de clasificación de calidad de agua basados en los valores del Índice Biótico de Familias (IBF) (Hilsenhoff 1988)

\begin{tabular}{lll}
\hline Biotic index & Water quality & Degree of organic pollution \\
\hline $0.00-3.50$ & Excellent & Organic pollution unlikely \\
$3.51-4.50$ & Very good & Possible slight organic pollution \\
$4.51-5.50$ & Good & Some organic pollution probable \\
$5.51-6.50$ & Fair & Fairly substantial pollution likely \\
$6.51-7.50$ & Fairly poor & Substantial pollution likely \\
$7.51-8.50$ & Poor & Very substantial pollution likely \\
$8.51-10.00$ & Very poor & Severe organic pollution likely \\
\hline
\end{tabular}

For each station, the abundance of each taxonomic group and the total abundance were calculated, expressed as individuals $\mathrm{m}^{-2}$. To estimate water quality the Hilsenhoff's Index (1988) was used, modified (FBI) for use at the species level (Appendix 1). Each taxon was assigned a tolerance value between 0 and 10, with 0 being the least tolerant to organic contamination and 10 the most tolerant. The tolerance values were established according to Barbour et al. (1999) and Mandaville (2002), and then classified into 7 quality classes (Table 2).

To determine the macroinvertebrate community structure we used the non-parametric similarity index of Bray-Curtis with Plymouth Routines in Multivariate Ecological Research software (PRIMER 6, Clarke \& Warwick 1994). The physico-chemical variables were found by MDS analysis. To compare the physico-chemical

\begin{tabular}{|c|c|c|c|c|c|}
\hline Group of compounds or elements & Unit & Exception Class & Class 1 & Class 2 & Class 3 \\
\hline Electrical conductivity & $\mu \mathrm{S} \mathrm{cm}^{-1}$ & $<600$ & 750 & 1,500 & 2,250 \\
\hline BOD5 & $m g L^{-1}$ & $<2$ & 5 & 10 & 20 \\
\hline Dissolved oxygen & $\mathrm{mg} \mathrm{L}^{-1}$ & $>7.5$ & 7.5 & 5.5 & 5 \\
\hline $\mathrm{pH}$ & - & $6.5-8.5$ & $6.5-8.5$ & $6.5-8.5$ & $6.5-8.5$ \\
\hline Suspended solids & $\mathrm{mg} \mathrm{L}^{-1}$ & $<24$ & 30 & 50 & 80 \\
\hline Temperature & $\Delta \mathrm{T}^{\circ} \mathrm{C}$ & $<0.5$ & 1.5 & 1.5 & 3 \\
\hline Chlorides & $\mathrm{mg} \mathrm{L}^{-1}$ & $<80$ & 100 & 150 & 200 \\
\hline Apparent colour & Unit $\mathrm{Pt} \mathrm{Co}^{-1}$ & $<16$ & 20 & 100 & $>100$ \\
\hline Sulphate & $\mathrm{mg} \mathrm{L}^{-1}$ & $<120$ & 150 & 500 & 1,000 \\
\hline Total dissolved solids & $\mathrm{mg} \mathrm{L}^{-1}$ & $<400$ & 500 & 1,000 & 1,500 \\
\hline
\end{tabular}


parameters among the sampling stations and seasons, a Principal Component Analysis (PCA) with physicochemical data transformed to $\log (x+1)$ was carried out using the same statistical program. A Pearson correlation analysis was performed to search for relations between fauna and the physico-chemical variables.

\section{RESULTS}

\section{MACROINVERTEBRATE COMMUNITY}

The macroinvertebrate fauna consisted of 77 taxa corresponding to 19 orders, specifically immature states of insects; Ephemeroptera (43.30\%), Diptera (24.16\%), Plecoptera (18.03\%), Coleoptera (5.41\%), Trichoptera (1.54\%) and others (7.56\%). A total of 6,889 individuals were captured; the most abundant species were Meridialaris diguillina, Nousia maculata and Limnoperla jaffueli.

In winter 1,992 ind. $\mathrm{m}^{-2}$ were collected; the most abundant species was Limnoperla jaffueli with 570 ind. $\mathrm{m}^{-2}$. In spring, 2,166 ind. $\mathrm{m}^{-2}$ were collected; the most abundant species was Meridialaris diguillina with 441 ind. $\mathrm{m}^{-2}$. In summer we collected 11,055 ind. $\mathrm{m}^{-2}$, of which Nousia maculata contributed 4,221 ind. $\mathrm{m}^{-2}$. In autumn we recorded 5,451 ind. $\mathrm{m}^{-2}$, the most abundant species again was Limnoperla jaffueli with 1,383 ind. $\mathrm{m}^{-2}$ (Table 3).

The cluster analysis showed that for all the sampling sites, existed was a $60 \%$ maximum similarity of taxa, specifically between sites 2 and 3 sampled during autumn. Two main groups were found through this analysis, according to the abundances of the taxa recorded, with 20\% similarity (Fig. 2).

The Pearson correlation analysis between the community and physico-chemical parameters showed a negative correlation between abundance and phosphate in spring and summer (-0.97 and -0.11 , respectively). In winter and autumn, a negative correlation was observed between abundance and nitrate $(-0.97$ and -0.85 , respectively).

\section{Physico-Chemical anAlysis OF THE WATER}

Water temperatures ranged between $8.7^{\circ} \mathrm{C}$ (Station 1 , autumn) and $21.6^{\circ} \mathrm{C}$ (Station 4 , summer). The conductivity varied between $14.4 \mu \mathrm{S} \mathrm{cm}^{-1}$ (Station 2, winter) and 47.7 $\mu \mathrm{S} \mathrm{cm}^{-1}$ (Station 1, summer). The $\mathrm{pH}$ varied between 6.07 (Station 3, autumn) and 6.90 (Station 1, summer), indicating slightly acidic waters (Table 4).

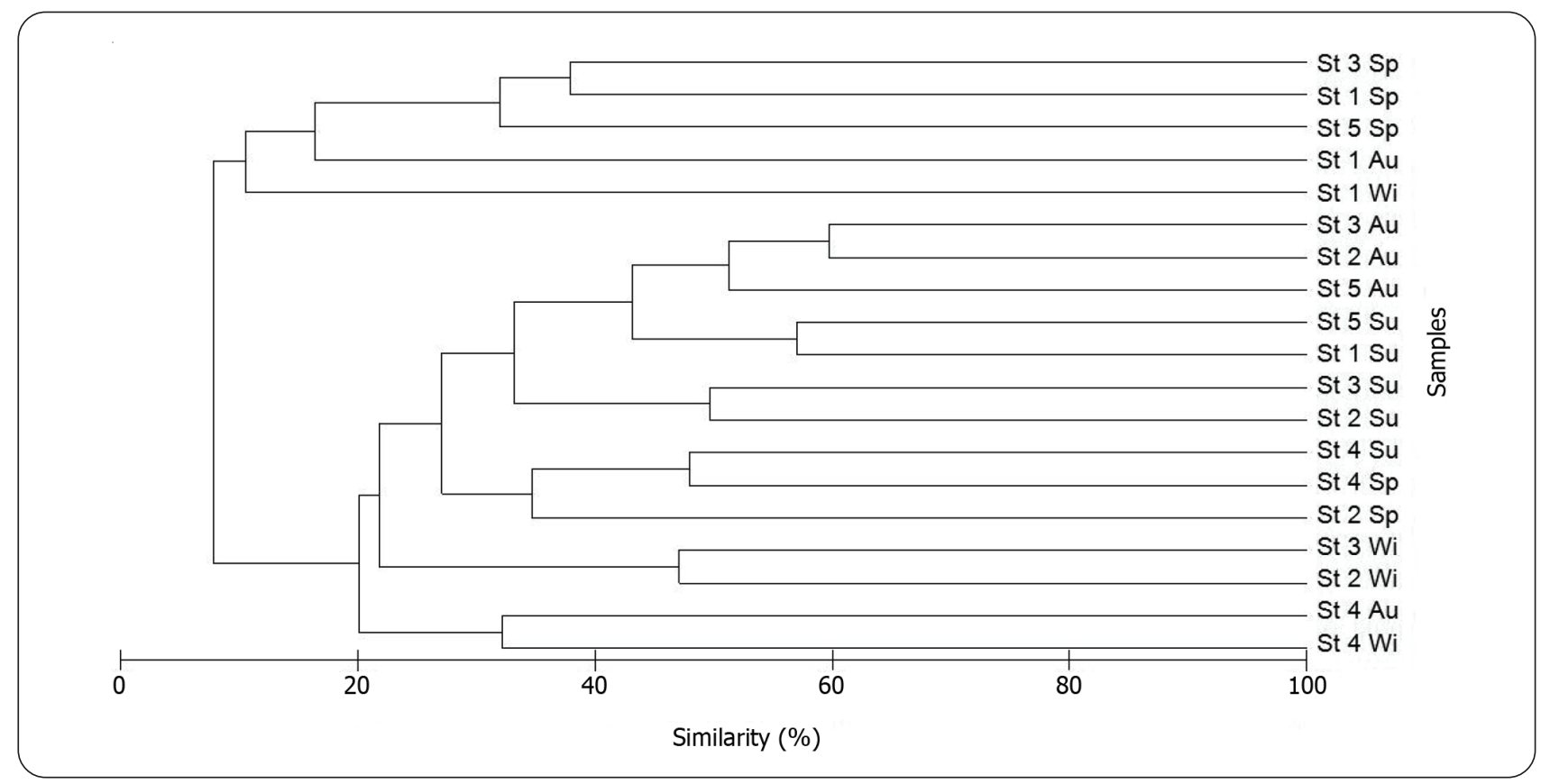

Figure 2. Cluster analysis grouping the sampling sites by the population abundance of macroinvertebrates from the Boroa River basin (Wi: winter, Sp: spring, Su: summer, Au: autumn) / Análisis de dendograma que agrupa los sitios de muestreo basado en la abundancia de la población de macroinvertebrados en la cuenca del Río Boroa (Wi: invierno, Sp: primavera, Su: verano, Au: otoño) 
Table 3. Taxonomic list of the benthic macroinvertebrates and their abundances (ind. $\mathrm{m}^{-2}$ ) recorded in the Boroa River basin. *: Indicates maximum abundance for each season of the year / Lista taxonómica de los macroinvertebrados bentónicos y sus abundancias (ind. $\mathrm{m}^{-2}$ ) registradas en la Cuenca del Río Boroa. *: Indican máximas abundancias en cada estación del año

\begin{tabular}{|c|c|c|c|c|c|c|c|c|c|}
\hline & Winter & Spring & Summer & Autumn & & Winter & Spring & Summer & Autumn \\
\hline \multicolumn{10}{|l|}{ Plecoptera } \\
\hline Klapopteryx armillata & 30 & 48 & 51 & 9 & Muscidae n/i & 0 & 0 & 3 & 0 \\
\hline Notoperlopsis femina & 9 & 39 & 207 & 219 & Symbiocladius wygodzinskyi & 0 & 12 & 18 & 0 \\
\hline Antarctoperla michaelseni & 0 & 3 & 0 & 15 & Corynoneura sp. & 6 & 66 & 327 & 0 \\
\hline Limnoperla jaffueli & $570^{*}$ & 21 & 972 & $1383^{*}$ & Eukiefferiella sp. & 9 & 81 & 552 & 135 \\
\hline Perlugoperla personata & 9 & 3 & 45 & 0 & Lopescladius sp. & 30 & 39 & 0 & 6 \\
\hline Senzilloides panguipullii & 12 & 0 & 0 & 0 & Orthocladius sp. & 0 & 51 & 72 & 42 \\
\hline Aubertoperla illiesi & 12 & 0 & 0 & 0 & Thienemanniella sp. & 27 & 12 & 54 & 0 \\
\hline Ceratoperla schwabei & 0 & 0 & 0 & 9 & Acricotopus sp. & 9 & 0 & 0 & 0 \\
\hline Kempnyella genualis & 0 & 3 & 24 & 3 & Pentaneura sp. & 3 & 123 & 453 & 9 \\
\hline Diamphipnopsis samali & 0 & 0 & 12 & 6 & Coelotanypus mendax & 0 & 0 & 12 & 0 \\
\hline Diamphipnoa helgae & 0 & 0 & 0 & 9 & Rheotanytarsus sp. & 36 & 0 & 180 & 273 \\
\hline Udamocercia sp. & 0 & 0 & 0 & 3 & Tanytarsus $\mathrm{sp}$. & 0 & 3 & 510 & 66 \\
\hline Ephemeroptera & & & & & Dicrotendipes sp. & 27 & 0 & 0 & 96 \\
\hline Chiloporter eatoni & 3 & 51 & 6 & 27 & Podonomus albinervis & 6 & 0 & 0 & 0 \\
\hline Andesiops peruvianus & 36 & 63 & 975 & 366 & Collembola & & & & \\
\hline Andesiops torrens & 72 & 24 & 3 & 147 & Collembola $\mathrm{n} / \mathrm{i}$ & 0 & 3 & 0 & 0 \\
\hline Hapsiphlebia anastomosis & 3 & 78 & 174 & 6 & Odonata & & & & \\
\hline Meridialaris diguillina & 93 & $441^{*}$ & 993 & 960 & Neogomphus sp & 0 & 3 & 39 & 9 \\
\hline Nousia maculata & 0 & 51 & $4221 *$ & 33 & & & & & \\
\hline Nousia delicata & 9 & 0 & 0 & 0 & Hemiptera & & & & \\
\hline Penaphlebia chilensis & 0 & 0 & 102 & 0 & Corixa sp. & 0 & 3 & 0 & 0 \\
\hline Rhigotopus andinensis & 0 & 0 & 3 & 0 & Decapoda & & & & \\
\hline Trichoptera & & & & & Aegla araucaniensis & 24 & 108 & 141 & 18 \\
\hline Brachysetodes sp. & 12 & 36 & 0 & 0 & Samastacus spinifrons & 0 & 0 & 9 & 0 \\
\hline Hydrobiosidae $n / i$ & 12 & 21 & 42 & 33 & Acariformes & & & & \\
\hline Neochorema sinuatum & 0 & 3 & 0 & 0 & Hydracarina $\mathrm{n} / \mathrm{i}$ & 0 & 0 & 3 & 0 \\
\hline Parasericostoma ovale & 3 & 3 & 21 & 6 & Torrenticola sp. & 9 & 0 & 0 & 3 \\
\hline Smicridea annulicornis & 0 & 18 & 30 & 18 & Pacommotonhar & & & & \\
\hline Austrotinodes sp. & 0 & 0 & 9 & 0 & Basommatophora & & & & \\
\hline Ecnomidae $\mathrm{n} / \mathrm{i}$ & 0 & 0 & 0 & 15 & Chilina dombeyana & 24 & 6 & 27 & 9 \\
\hline Hydroptilidae $\mathrm{n} / \mathrm{i}$ & 0 & 0 & 6 & 0 & Mesogastropoda & & & & \\
\hline Oxyethira sp. & 0 & 0 & 12 & 0 & Littoridina cuming $i$ & 27 & 9 & 12 & 51 \\
\hline Dolophilodes sp. & 0 & 0 & 3 & 0 & Pulmonata & & & & \\
\hline Polycentropus sp. & 0 & 0 & 12 & 3 & PuImonata & 0 & 0 & & \\
\hline Coleoptera & & & & & Lymnaea viator & 0 & 0 & 3 & 6 \\
\hline Tychepsephenus felix & 0 & 15 & 9 & 9 & Veneroida & & & & \\
\hline Austrolimnius sp. & 0 & 231 & 498 & 312 & Pisidium chilense & 0 & 0 & 3 & 0 \\
\hline Luchoelmis sp. & 0 & 6 & 9 & 0 & Tubificida & & & & \\
\hline Austrelmis sp. & 24 & 0 & 0 & 0 & Tubifex sp. & 345 & 0 & 54 & 234 \\
\hline Curculionidae $\mathrm{n} / \mathrm{i}$ & 0 & 3 & 0 & 0 & & & & & \\
\hline Haliplidae $\mathrm{n} / \mathrm{i}$ & 0 & 0 & 3 & 0 & Annellda & & & & \\
\hline Diptera & & & & & $\begin{array}{l}\text { Naididae } \\
\text { Stratiodriluc anhilus }\end{array}$ & 0 & 0 & 0 & 12 \\
\hline Alluaudomyia sp. & 12 & 42 & 12 & 3 & Stratiodrilus aeglaphilus & 3 & 0 & 0 & 0 \\
\hline Stilobezzia sp. & 6 & 0 & 0 & 78 & Arhynchobdellida & & & & \\
\hline Atherix sp. & 3 & 96 & 9 & 0 & Mesobdella sp. & 3 & 0 & 0 & 0 \\
\hline Hemerodromia sp. & 0 & 21 & 6 & 3 & Temnocephalida & & & & \\
\hline Hexatoma sp. & 129 & 216 & 87 & 696 & Temnocephala chilensis & 324 & 27 & 3 & 0 \\
\hline Limonia sp. & 0 & 84 & 12 & 78 & icladida & & & & \\
\hline Blephariceridae & 0 & 0 & 0 & 3 & IItcraura & & & & \\
\hline Gigantodax sp. & 21 & 0 & 3 & 24 & Dugesia anceps & 0 & 0 & 9 & 6 \\
\hline
\end{tabular}

n/i : no identificado 


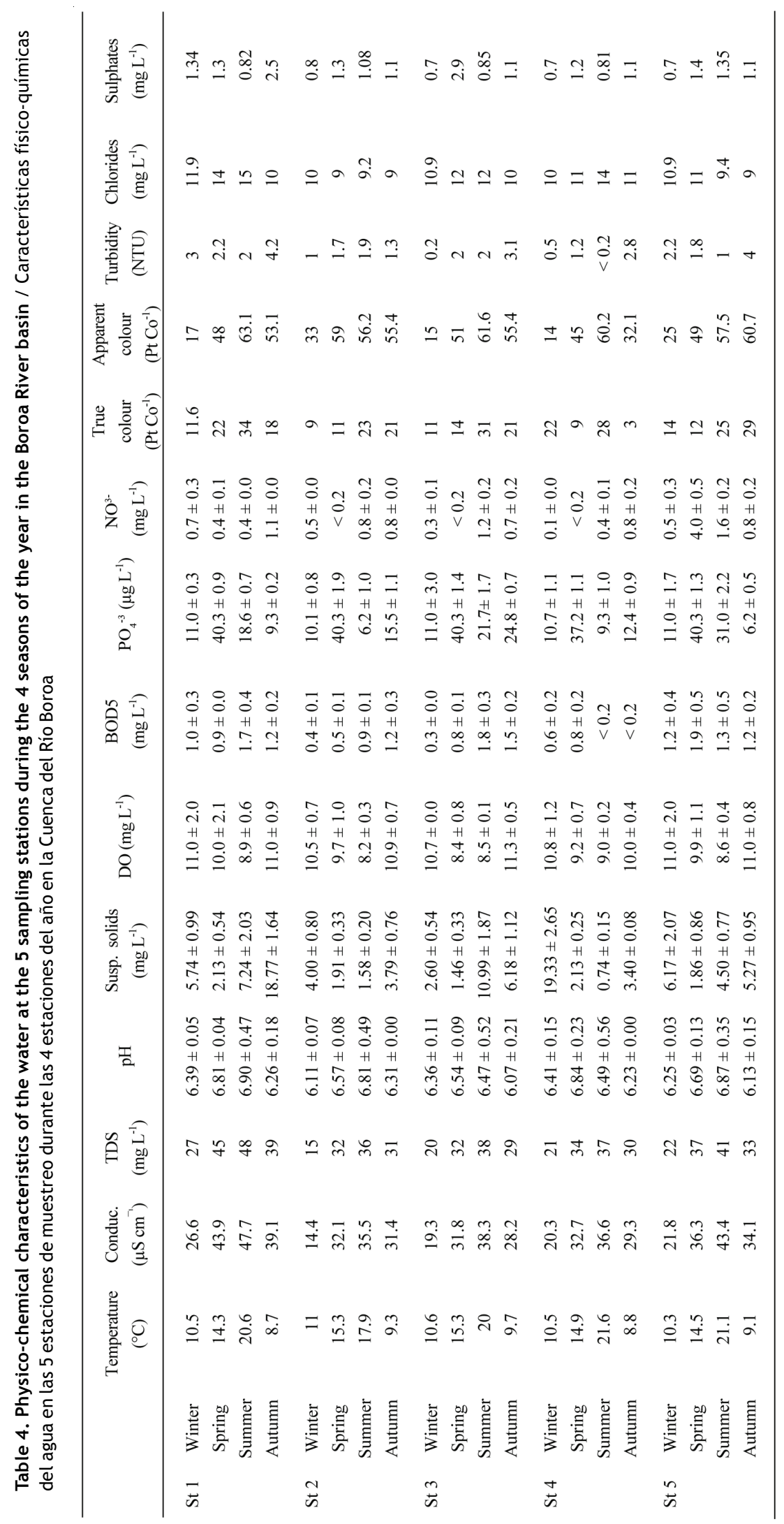


Our results, using physico-chemical variables as the principal parameter for classifying water quality, indicated exceptional water quality for the whole Boroa River basin according to the secondary environmental quality standard for the protection of Chilean continental waters (CONAMA 2004). The only parameter which exceeded the permitted limits for waters of exceptional quality was the apparent colour.

The first two axes of the principal component analysis (PCA), for the physico-chemical variables and the sampling stations, explained $57 \%$ of the accumulated variability, the first was related to the temperature and dissolved oxygen and the second to turbidity (Fig. 3).

The MDS analysis between sampling seasons found a similarity between the spring and summer seasons and between autumn and winter (Fig. 4).

\section{INDEX BIOTIC}

Over the course of the year the biotic water quality index (Hilsenhoff 1988) varied; for the coastal basin of the Boroa River water quality varied from excellent $(<3.5)$, i.e., unlikely to present organic pollution, to good (4.51-5.50), i.e., with some organic pollution probable. The highest values were recorded in winter at stations 3 and 4 (Table 5).

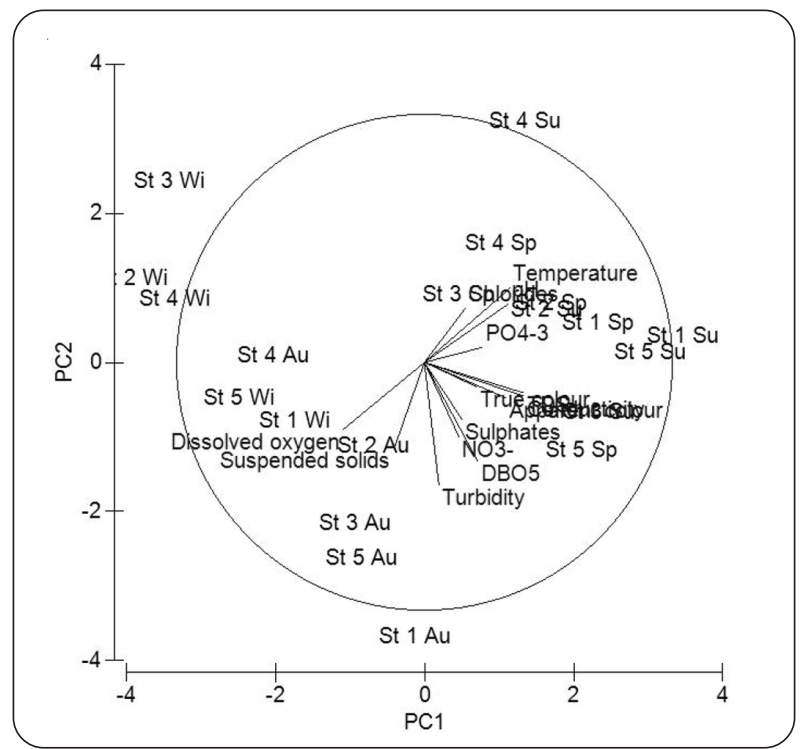

Figure 3. Results of the principal component analysis (PCA) for the sampling stations in the Boroa River basin during the 4 seasons of the year, based on the physico-chemical variables of the water (Wi: winter, Sp: spring, Su: summer, Au: autumn) / Resultados del análisis de componentes principales (PCA) de las estaciones de muestreo en la cuenca del Río Boroa durante las 4 estaciones del año, basados en las variables físico-químicas del agua (Wi: invierno, Sp: primavera, Su: verano, Au: otoño)

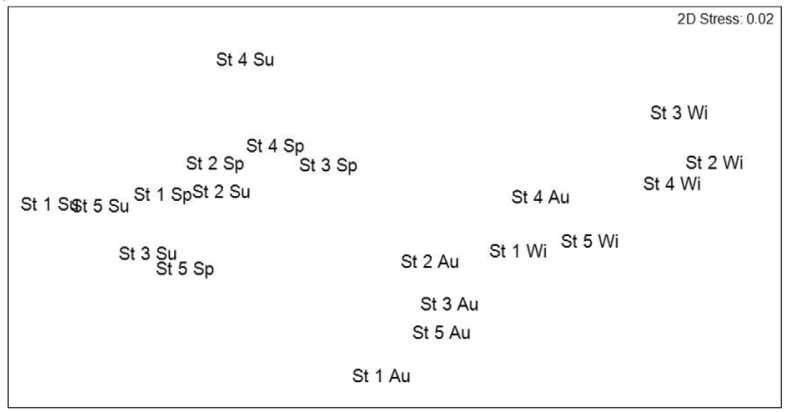

Figure 4. Results of the Multidimensional Scaling (MDS) for the sampling stations of the Boroa River basin during the 4 seasons of the year, based on the standardized physico-chemical variables and using Euclidian distances as measures of similarity (Wi: winter, Sp: spring, Su: summer, Au: autumn) / Resultados del Escalamiento Multidimensional (MDS) de las estaciones de muestreo de la cuenca del Río Boroa durante las 4 estaciones del año, basados en las variables físico-químicas estandarizadas y usando distancia Euclidiana como medida de similitud (Wi: invierno, Sp: primavera, Su: verano, Au: otoño)

Table 5. Modified Hilsenhoff biotic index values for the Boroa River at the 5 stations sampled during the 4 seasons of the year $(E=$ Excellent, $V G=$ Very good, $G=$ Good $) /$ Valores del Índice biótico de Hilsenhoff modificado para la cuenca del Río Boroa en las 5 estaciones de muestreo durante las 4 estaciones del año ( $\mathrm{E}=$ Excelente, $\mathrm{VG}=$ Muy bueno, $\mathrm{G}=$ Bueno)

\begin{tabular}{lccccccccc}
\hline & Winter & \multicolumn{2}{c}{ Spring } & Summer & \multicolumn{2}{c}{ Autumn } \\
\hline Station 1 & 3.55 & VG & 3.32 & E & 3.12 & E & 4.51 & G \\
Station 2 & 3.81 & VG & 3.87 & VG & 4.11 & VG & 4.4 & VG \\
Station 3 & 5.15 & G & 4 & VG & 3.17 & E & 3.8 & VG \\
Station 4 & 4.75 & G & 3.71 & VG & 3.65 & VG & 3.29 & E \\
Station 5 & - & - & 4.3 & VG & 3.34 & E & 3.17 & E \\
\hline
\end{tabular}

\section{Discussion}

In the present study, 77 taxa of benthic macroinvertebrates were recorded from the Boroa River basin (12,910.73 ha). The basin had greater richness in comparison with other similar-sized basins located in southern Chile. For example, in the basin of the Peu Peu stream, 15,333.67 ha, 25 taxa were recorded in 5 stations (Leiva 2004); in the basin of the Cayucupil River, 12,200 ha, 36 taxa in 3 stations (Moya et al. 2009b). It may even be compared to a basin which is four times larger, the Damas River basin covering 51,400 ha, where 14 stations were sampled (Figueroa et al. 2003), showed the same number of taxa as was recorded in the Boroa basin. This high number of taxa may be due to the low level of anthropic intervention, since one of the factors causing the strongest negative effect on the abundance and diversity of aquatic invertebrates is the 
indiscriminate use of fertilizers, especially phosphate and nitrate, which contribute to an increase in eutrophication in the system, modifying biological conditions, reducing diversity and even causing the death of organisms (Arheimer et al. 2004, Alonso \& Camargo 2005, Durán 2006, Martínez et al. 2007). The low levels of phosphates recorded in the Boroa River basin showed a negative correlation with abundance during the drier seasons, just as the low levels of nitrate showed a negative correlation with abundance in the wet seasons. However, TawariFufeyin et al. (2008) described high levels of nutrients (phosphate and nitrate) in the rainy season corresponding with periods of high taxa richness in the Ossiomo River.

It is known that the abundance of many elevationsensitive species diminishes from higher to lower elevations within basins (e.g., Figueroa et al. 2003, 2007, Miserendino 2006). However, a few sensitive mayfly and stonefly species (Stoyanova et al. 2010) were also recorded in the lower parts of the basin. Giacometti \& Bersosa (2006) in the Alambi River (Ecuador) and Bonada et al. (2000) in the Sant Cugat River basin (Spain) recorded communities of macroinvertebrates characteristic of clean waters in the lower-lying zones. These rivers have good self-cleaning mechanisms which allow survival of these communities. In the case of the Boroa River this situation was corroborated by the physico-chemical parameters, which indicated exceptional water quality throughout the basin. The most abundant taxa reaching the lowest areas were a gripopterygid stoneflies, Limnoperla jaffueli, and the Leptophlebiid mayflies Nousia maculata and Meridialaris diguillina. The latter order has been recorded in nearby water systems such as the Valdivia Coastal Reserve, in the Los Ríos Region (GuevaraCardona et al. 2006) and the Itata River, Biobío Region (Habit et al. 1998), where it was the most dominant taxon.

The lower abundances of taxa recorded in spring may be due to factors related to the climate, physical habitat and the trophic bases of the water systems (Whiles et al. 2000), and an important factor to be considered is the season when insects emerge. In this respect there are records regarding bodies of water close to the Boroa River which show low synchronization in the flight season of Plecoptera (Caamaño 1985) and one Ephemeroptera (Gonser \& Spies 1997); this conflicts with the results of Hollmand \& Miserendino (2008), who mentioned that the majority of Plecoptera in southern Argentina presented defined periods of emergence (spring-summer), which agrees with our results.

In the Boroa River a significantly greater number of individuals and species were recorded in summer than in winter, in agreement with observations made in the rivers of Ecuador (Jacobsen \& Encalada 1998, Giacometti \& Bersosa 2006). Thus, the fact that a lower abundance of macroinvertebrates was recorded in winter may be due to the high rainfall, increased flow of the river and greater turbidity, the latter being one of the axes which contributed the most to explain the variability of the physico-chemical parameters. We suggest that this relationship should be studied further, with a closer analysis of the life cycles of aquatic insects.

One of the most commonly used biological methods employed to evaluate water quality is the use of benthic macroinvertebrates (Leunda et al. 2009), which allow for the detection of temporal episodes that occur during seasons and between sampling stations, that physicochemical parameters cannot establish (Giacometti \& Bersosa 2006, Figueroa et al. 2007). Thus, the combination of biological and physico-chemical methods proposed by Duran (2006) appears to be the best alternative for the determination of water quality. According to our physicochemical analysis, the water quality results classified the Boroa River as of exceptional quality. Nevertheless, the apparent colour parameter in some stations exceeded the limit, possibly due to colloidal matter in suspension. The Biotic Index used proved to be a more accurate method than the one previously described, since it allowed us to define different water qualities that the physico-chemical method did not detect.

The variability of water quality given by the biotic index has been documented by various authors, and may be seasonal (Murphy 1978, Gratwicke 1999), or influenced by differences between sites (Zamora-Muñoz et al. 1995). Water quality values obtained through application the index biotic changed seasonally in the Boroa basin. In winter, physico-chemical parameters did not show any variation; however, the increased flow resulted in increased macroinvertebrate drift, contributing to the lower density, increasing the biotic index values and decreasing water quality, but always from very good to good. The opposite was found in summer, high abundance and diversity of taxa were recorded, with lower biotic index values indicating better water quality, ranging from very good to excellent. Thus, according to Linke et al. (1999), seasonality must be taken into account when using aquatic macroinvertebrates as bioindicators, since this phenomenon may influence the results of biomonitoring analyses. Certainly the seasonal variation in biotic index values in watersheds of southern Chile must be taken into account when designing water quality monitoring based on biotic indices. 
Hopefully this investigation will inspire future workers to refine the application of biotic indices using benthic macroinvertebrates to monitor organic pollution in other river basins of southern Chile. This will require species level keys in the future to enable more sensitive biomonitoring studies. Periodic biomonitoring of organic contamination in river basins is needed to allow state environmental agencies to take steps to maintain the biotic integrity of streams and rivers in southern Chile.

\section{ACKnowledgments}

The authors wish to thank Raúl Arriagada and Eduardo Fernández for their assistance in the field; and Dr. Luciano Caputo for his comments on this work. This study was financed by FONDECYT Projects 1080317 and 1110798. The authors would like to thank the editor and two anonymous reviewers for helpful comments on an early version of this manuscript and assistance provided by DID (Dirección de Investigación de Desarrollo) of the Universidad Austral de Chile.

\section{LITERATURE CITED}

Alba-Tercedor J. 1996. Macroinvertebrados acuáticos y calidad de agua de los ríos. IV Simposio del agua en Andalucía (SIAGA). Almería 2: 203-213.

Alonso A \& JA Camargo. 2005. Estado actual y perspectivas en el empleo de la comunidad de macroinvertebrados bentónicos como indicadora del estado ecológico de los ecosistemas fluviales españoles. Ecosistemas 14(3): 87-99.

APHA. 1992. Standard methods for the examination of water and wastewater, pp. 2-47. American Public Health Association, Washington.

Arheimer B, G Torstensson \& H Wittgren. 2004. Landscape planning to reduce coastal eutrophication: agricultural practices and constructed wetlands. Landscape and Urban Planning 67: 205-215.

Barbour M, J Gerritsen, BD Snyder \& JB Stribling. 1999. Rapid bioassessment protocols for use in streams and wadeable rivers: Periphyton, benthic macroinvertebrates and fish. EPA 841-B-99-002. United States Environmental Protection Agency; Office of Water, Washington. [on line] $<$ http://water.epa.gov/scitech/monitoring/rsl/bioassessment/ index.cfm>

Bonada N, M Rieradevall \& N Prat. 2000. Temporalidad y contaminación como claves para interpretar la biodiversidad de macroinvertebrados en un arroyo mediterráneo (Riera de Sant Cugat, Barcelona). Limnética 18(1): 81-90.

Caamaño M. 1985. Taxonomía de las ninfas terminales de Plecoptera (Insecta) en tres ritrones preandinos de Riñihue, $\mathrm{X}$ región, Chile. Tesis de Grado, Facultad de Ciencias, Universidad Austral de Chile, Valdivia, 146 pp.

Chutter F. 1972. An empirical biotic index of the quality of water in South African streams and rivers. Water Research 6: 19-30.
Clarke KR \& M Warwick. 1994. Change in marine communities: an approach to statistical analysis and interpretation, $144 \mathrm{pp}$. Plymouth Marine Laboratory, Natural Environment Research Council, Plymouth.

CONAMA. 2004. Guía relativa al desarrollo de la dictación de normas secundarias de calidad ambiental para aguas continentales superficiales y aguas marinas NSCA, 23 pp. Comisión Nacional del Medio Ambiente, Santiago de Chile.

Domínguez E \& H Fernández. 2009. Macroinvertebrados bentónicos sudamericanos. Sistemática y biología, $656 \mathrm{pp}$. Fundación Miguel Lillo, Tucumán.

Durán M. 2006. Monitoring water quality using benthic macroinvertebrates and physico-chemical parameters of Behzat stream in Turkey. Polish Journal of Environmental Studies 15(5): 709-717.

Fernández H \& E Domínguez. 2001. Guía para la determinación de artrópodos bentónicos sudamericanos, 450 pp. Serie Investigaciones de la UNT, Subserie Ciencias Exactas y Naturales, Tucumán.

Figueroa R, C Valdovinos, E Araya \& O Parra. 2003. Macroinvertebrados bentónicos como indicadores de calidad de agua del sur de Chile. Revista Chilena de Historia Natural 76: 275-285.

Figueroa R, V Ruíz, F Encina \& A Palma. 2005. Simplificación en el uso de macroinvertebrados en la evaluación de la calidad de las aguas en sistemas fluviales. Interciencia 30(12): 770774.

Figueroa R, A Palma, V Ruiz \& X Niell. 2007. Análisis comparativo de índices bióticos utilizados en la evaluación de la calidad de las aguas en un río mediterráneo de Chile: río Chillán, VIII Región. Revista Chilena de Historia Natural 80: 225-242.

Furse M, D Moss, J Wright \& P Armitage. 1984. The influence of seasonal and taxonomic factors on the ordination and classification of running-water sites in Great Britain and on the prediction of their macro-invertebrates communities. Freshwater Biology 14: 257-280.

Giacometti J \& F Bersosa. 2006. Macroinvertebrados acuáticos y su importancia como bioindicadores de calidad del agua en el río Alambi. Boletín Técnico 6, Serie Zoológica 2: 17-32.

Gonser T \& M Spies. 1997. Southern Hemisphere Symbiocladius (Diptera, Chironomidae) and their mayfly hosts (Ephemeroptera, Leptophlebiidae). In: Landolt P \& M Sartori (eds). Ephemeroptera and Plecoptera: Biology ecology -systematics, pp. 455-466. Mauron and Tinguely \& Lanchat, Fribourg.

Gratwicke B. 1999. The effect of season on a biotic water quality index: A case study of the Yellow jacket and Mazowe rivers, Zimbawe. South Africa Journal of Aquatic Science 24(1): 24-35.

Guerold F. 2000. Influence of taxonomic determination level on several community indices. Water Research 34: 487-492. 
Guevara-Cardona G, C Jara, M Mercado \& S Elliott. 2006. Comparación del macrozoobentos presente en arroyos con diferente tipo de vegetación ribereña en la reserva costera Valdiviana, Sur de Chile. Asociación Colombiana de Limnología 'Neolimnos' 1: 98-105.

Habit E, C Bertrán, S Arévalo \& P Victoriano. 1998. Benthonic fauna of the Itata River and irrigation canals (Chile). Irrigation Science 18: 91-99.

Hawkins C \& J Sedell. 1980. Longitudinal and seasonal changes in functional organization of macroinvertebrate communities in four Oregon streams. Ecology 62(2): 387397.

Hilsenhoff W. 1988. Rapid field assessment of organic pollution with a family-level biotic index. Journal of the North American Benthological Society 7(1): 65-68.

Hollmand M \& L Miserendino. 2008. Life history and emergence patterns of stonefly species in mountain streams of the Futaleufú basin, Patagonia (Argentina). Annales de Limnology - International Journal of Limnology 44: 1-10.

Jacobsen D \& A Encalada. 1998. The macroinvertebrate fauna of Ecuadorian Highland streams in wet and dry seasons. Archive Fuer Hydrobiologie 142(1): 53-70.

Leiva M. 2004. Macroinvertebrados bentónicos como bioindicadores de calidad de agua en la cuenca del estero Peu Peu comuna de Lautaro IX región de la Araucanía. Tesis de grado, Facultad de Ciencias, Universidad Católica de Temuco, Temuco, 111 pp.

Leunda P, J Oscoz, R Miranda \& AAriño. 2009. Longitudinal and seasonal variation of the benthic macroinvertebrate community and biotic indices in an undisturbed Pyrenean river. Ecological Indicators 9: 52-63.

Linke S, R Bailey \& J Schwindt. 1999. Temporal variability of stream bioassessments using benthic macroinvertebrates. Freshwater Biology 42: 575-584.

Mandaville S. 2002. Benthic macroinvertebrates in freshwaters-taxa tolerance values, metrics, and protocols. Proyect H-1. Soil \& Water Conservations Society of Halifax. [on line] < http://lakes.chebucto.org/H-1/tolerance.pdf>

Martínez J \& M Esteve. 2007. Gestión integrada de cuencas costeras: dinámica de los nutrientes en la cuenca del Mar Menor (sudeste de España). Revista de Dinámica de Sistemas 3(1): 2-20.

Martínez J, J Martínez \& M Esteve. 2007. Evaluación económica del tratamiento de drenajes agrícolas en el Mar Menor (SE España). Revista Española de Estudios Agrosociales y Pesqueros 215: 211-232.

Mercado M \& S Elliott. 2006. Taxonomic revision of the Genus Chaquihua Demoulin (Ameletopsidae: Ephemeroptera) with notes on its biology and distribution. Studies of Neotropical Fauna and Environment 41(1): 59-66.

Miserendino L. 2006. Seasonal and spatial distribution of stoneflies in the Chubut River (Patagonia, Argentina). Hydrobiologia 568: 263-274.
Moya C, C Suárez, G Mancilla \& M Henríquez. 2009a. Catastro biológico de la flora y fauna terrestre y acuática del sistema fluvial Cayucupil, provincia de Arauco, Región del Bio Bio. Calbatué. Consultores Ambientales, 48 pp.

Moya C, C Valdovinos, A Moraga, F Romero, P Debels \& A Oyanedel. 2009b. Patrones de distribución espacial de ensambles de macroinvertebrados bentónicos de un sistema fluvial Andino Patagónico. Revista Chilena de Historia Natural 82: 425-442.

Murphy P. 1978. The temporal variability in biotic indices. Environmental Pollution. 17: 227-236.

Oscoz J, J Gommà, L Ector, J Cambra, M Pardos \& C Durán. 2007. Estudio comparativo del estado ecológico de los ríos de la cuenca del Ebro mediante macroinvertebrados y diatomeas. Limnetica 26(1): 143-158.

Oyanedel A, C Valdovinos, C Moya, M Azocar, G Mancilla \& R Figueroa. 2008. Patrones de distribución espacial de los macroinvertebrados bentónicos de la cuenca del río Aysen. Gayana 72: 241-257.

Peña-Cortés F, P Gutiérrez, G Rebolledo, M Escalona, E Hauenstein, C Bertrán, R Schlatter \& J Tapia. 2006. Determinación del nivel de antropización de humedales como criterio para la planificación ecológica de la cuenca del lago Budi, IX Región de la Araucanía, Chile. Revista de Geografía Norte Grande 36: 75-91.

Peña-Cortés F, J Pincheira-Ulbrich, C Bertrán, J Tapia, E Hauenstein, E Fernández \& D Rosas. 2011. A study of the geographic distribution of swamp forest in the coastal zone of the Araucanía Region, Chile. Applied Geography 31: 545-555.

Roldán G. 1999. Los macroinvertebrados y su valor como indicadores de la calidad del agua. Revista de la Academia Colombiana de Ciencias Exactas, Físicas y Naturales 23(88): 375-387.

Stoyanova T, I Traykov, I Yaneva \& V Bogoev. 2010. Ecological quality assessment of Luda River, Bulgaria. Natura Montenegrina, Podgorica 9(3): 341-348.

Tawari-Fufeyin P, BN Iloba \& E Unuajohwofia. 2008. Evaluating the water quality of Ossiomo River using macroinvertebrates associated with water hyacinth (Eichornia natans). Bioscience Research Communications 20(6): 283-291.

Vannote R, G Minshall, K Cummins, J Sedell \& C Cushing. 1980. The river continuum concept. Canadian Journal of Fisheries and Aquatic Science 37: 130-137.

Valdovinos C. 2001. Riparian leaf litter processing by benthic macroinvertebrates in a woodland stream of central Chile. Revista Chilena de Historia Natural 74: 445-453.

Waite I, A Herlihy, D Larsen, S Urquhart \& D Klemm. 2004. The effects of macroinvertebrate taxonomic resolution in large landscape bioassessments: an example from the Mid-Atlantic Highlands, U.S.A. Freshwater Biology 49: 474-489.

Warwick R. 1988. The level of taxonomic discrimination required to detect pollution effects on Marine benthic communities. Marine Pollution Bulletin 19(6): 259-268. 
Whiles M, B Brock, A Franzen \& S Dinsmore. 2000. Stream invertebrate communities, water quality, and land-use patterns in a agricultural drainage basin of Northeastern Nebraska, USA. Environmental Management 26(5): 563-576.
Zamora-Muñoz C, CE Sainz-Cantero, A Sanchez-Ortega \& J Alba-Tercedor. 1995. Are biological indices BMPW' and ASPT' and their significance regarding water quality seasonally dependent? Factors explaining their variations. Water Research 29: 285-290.

Appendix 1. Tolerance values (TV) of benthic macroinvertebrates of the Boroa River, Chile used for the Family Biotic Index (FBI), according to Barbour et al. (1999) and Mandaville (2002) / Valores de tolerancia (TV) de los macroinvertebrados bentónicos del Río Boroa, Chile usados para el Índice Biótico de Familias (IBF), siguiendo a Barbour et al. (1999) y Mandaville (2002)

\begin{tabular}{|c|c|c|c|c|c|}
\hline & Species & TV & & Species & TV \\
\hline \multicolumn{3}{|l|}{ Plecoptera } & Chironomidae & Corynoneura sp. & 4 \\
\hline Austroperlidae & Klapopteryx armillata & 0 & & Eukiefferiella sp. & 4 \\
\hline \multirow[t]{7}{*}{ Grypopterygidae } & Notoperlopsis femina & 0 & & Lopescladius sp. & 5 \\
\hline & Antarctoperla michaelseni & 1 & & Orthocladius sp. & 6 \\
\hline & Limnoperla jaffueli & 2 & & Thienemanniella sp. & 6 \\
\hline & Perlugoperla personata & 1 & & Acricotopus sp. & 10 \\
\hline & Senzilloides panguipullii & 1 & & Pentaneura sp. & 5 \\
\hline & Aubertoperla illiesi & 0 & & Coelotanypus mendax & 4 \\
\hline & Ceratoperla schwabei & 1 & & Rheotanytarsus sp. & 6 \\
\hline Perlidae & Kempnyella genualis & 0 & & Tanytarsus sp. & 6 \\
\hline \multirow[t]{2}{*}{ Diamphipnoidae } & Diamphipnopsis samali & 0 & & Dicrotendipes sp. & 8 \\
\hline & Diamphipnoa helgae & 0 & & Podonomus albinervis & 1 \\
\hline \multirow[t]{2}{*}{ Notonemouridae } & Udamocercia sp & 0 & & & \\
\hline & & & Collembola & & \\
\hline \multicolumn{3}{|l|}{ Ephemeroptera } & Collembola & Collembola & 5 \\
\hline Ameletopsidae & Chiloporter eatoni & 2 & & & \\
\hline \multirow[t]{2}{*}{ Baetidae } & Andesiops peruvianus & 4 & Odonata & & \\
\hline & Andesiops torrens & 5 & Gomphidae & Neogomphus sp. & 5 \\
\hline \multirow[t]{7}{*}{ Leptophlebiidae } & Hapsiphlebia anastomosis & 2 & & & \\
\hline & Meridialaris diguillina & 4 & Hemiptera & & \\
\hline & Nousia maculata & 3 & Corixidae & Corixa sp. & 4 \\
\hline & Nousia delicata & 3 & & & \\
\hline & Penaphlebia chilensis & 4 & Decapoda & & \\
\hline & Rhigotopus andinensis & 2 & Aeglidae & Aegla araucaniensis & 5 \\
\hline & & & Parastacidae & Samastacus spinifrons & 5 \\
\hline \multicolumn{6}{|l|}{ Trichoptera } \\
\hline Leptoceridae & Brachysetodes sp. & 4 & Acariformes & & \\
\hline \multirow[t]{2}{*}{ Hydrobiosidae } & Hydrobiosidae & 3 & Hydracarina $\mathrm{n} / \mathrm{i}$ & Hydracarina & 6 \\
\hline & Neochorema sinuatum & 3 & Torrenticolidae & Torrenticola sp. & 6 \\
\hline Sericostomatidae & Parasericostoma ovale & 5 & & & \\
\hline Hydropsychidae & Smicridea annulicornis & 5 & Basommatophora & & \\
\hline \multirow[t]{2}{*}{ Ecnomidae } & Austrotinodes sp. & 5 & Chilinidae & Chilina dombeyana & 7 \\
\hline & Ecnomidae & 5 & & & \\
\hline
\end{tabular}

Received 15 September 2011 and accepted 19 January 2012 